\title{
Pemanfaatan Lahan Sempit Untuk Meningkatkan Gizi, Pendapatan dan Sumber Pengobatan Keluarga
}

\author{
Efi Nikmatu Sholihah ${ }^{l)}$, Endang Sri Sudalmi ${ }^{2}$, JM Sri Hardiatmi ${ }^{3)}$, \\ Sadewo Wahyu Wibowo ${ }^{4}$, Pandu Prayoga ${ }^{5)}$ \\ 1) 2) 3) 4) 5) Universitas Slamet Riyadi, Surakarta, Indonesia
}

Corresponding Author: Efi Nikmatu Sholihah, efinikmatus@gmail.com

\begin{abstract}
Abstrak: Sebagian besar lahan pekarang diperkotaan belum di manfaatkan secara optimal, dengan pemanfaatan lahan pekarangan diperkotaan diharapkan dapat mendorong kesejahteraan masyarakat. Tujuan dari kegiatan pengabdian kepada masyarakat ini adalah meningkatkan pemanfaatan lahan pekarangan dengan tanaman hortikultura dan tanaman obat keluarga (TOGA). Metode yang digunakan untuk mencapai tujuan kegiatan ini adalah dengan pemberdayaan masyarakat tentang pemanfaatan lahan sempit yang terbengkalai dilingkungan sekitar, masyarakat diberikan pengetahuan mengenai peranan pekarangan dalam meningkatkan gizi, pendapatan, dan sumber pengobatan bagi keluarga melalui ceramah dan diskusi. Setelah memperoleh pengetahuan mengenai peranan pekarangan, masyarakat diberikan contoh secara langsung melalui penanaman tanaman sayuran dan obat-obatan sebagai langkah pemanfaatan lahan pekarangan secara intensif. Berdasarkan percontohan yang dilakukan, anggota masyarakat di RT.03/RW.XVII Kelurahan Sumber Kecamatan Banjarsari Kota Surakarta mudah memahami manfaat dari pemanfaatan lahan pekarangan yang dimiliki dan tertarik untuk empraktekkannya lebih lanjut karena waktu panen yang relatif singkat dan proses penanaman yang cukup mudah.
\end{abstract}

Kata Kunci: Pekarangan, Tanaman Hortikultura, Tanaman Obat

Abstract: Most of the land in the city has not been utilized optimally, with the use of yardland in the city is expected to encourage the welfare of the community. The objectives of this community service activity are : increasing the utilization of yard land with horticultural cultivation and family medicinal plants (TOGA). The method used to achieve the objectives of this activity is community empowerment regarding the use of narrow, neglected land in the surrounding environment, the community is given knowledge about the role of the yard in increasing nutrition, income, and sources of treatment for the family through lectures and discussions. After gaining knowledge about the role of the yard, the community is given direct examples by planting vegetables and medicines as a step towards intensive use of their yardland. Based on the pilot carried out, community members in RT.03 / RW.XVII Kelurahan Sumber, Banjarsari District, Surakarta City easily understood the benefits of using their yards and were interested in further practice because of the relatively short harvest time and relatively easy planting process.

Keywords: yard, horticultural plants, medicinal plants

\section{Pendahuluan}

Daerah peerkotaan dan pedesaan mengalami peningkatan yang pesat pada beberapa dekade terakhir. Peningkatan perekonomian terutama di daerah perkotaan menjadikan tingkat pembangunan di daerah tersebut semakin tinggi. Hal tersebut menjadikan lahan perumahan di desa maupun di perkotaan mengalami penyusutan dan kepemilikan lahan masing-masing individu menjadi lebih sempit.

Submitted: 26.10.2020, Revised: 04.02.2021, Accepted: 05.04.2021 
Pada umumnya lahan pekarangan di daerah perkotaan memiliki luasan yang sempit. Demikian juga keadaan lahan pekarangan di RT.03/ RW.XVII Kelurahan Sumber, Kecamatan Banjarsari, Kota Surakarta. Pengembangan bidang pertanian yang saat ini telah dilaksanakan masih terfokus pada lahan sawah, dan pengelolaan pekarangan belum banyak diperhatikan (Haerudin, 2010). Menurut Ashari, Saptana, \& Purwantini (2012) dengan pemanfaatan lahan pekarangan secara optimal dan terencana, diharapkan masyarakat dapat memenuhi kebutuhan pangan keluarga dan juga dapat memperoleh penghasilan tambahan diluar penghasilah dari pekerjaan utama.

Menurut Lais, Pangemanan, \& Jocom (2017) pemenuhan kebutuhan pangan masingmasing individu dapat dilakukan melalui pemanfaatan pekarangan secara optimal, kegiatan tersebut dapat menurunkan tingkat kerawanan pangan sekaligus sebagai upaya pemenuhan gizi dan peningkatan pendapatan keluarga. Secara umum, masalah yang dihadapi masyarakat dalam upaya pemanfaatan pekarangan adalah kurangnya pengetahuan dan pelatihan mengenai teknik budidaya yang tepat (Dwiratna, Widyasanti, \& Rahmah, 2016). Hal yang utama adalah lahan pekarangan memiliki fungsi membantu masyarakat dalam penyediaan bahan pangan dan tanaman obat yang untuk anggota keluarga dan masyarakat sekitar. Disebut taman gizi, karena dari pekarangan dapat diperoleh bahan-bahan seperti: sayur-sayuran untuk bahan makanan dan tanaman empon-empon sebagai sumber pengobatan keluarga. Bahan-bahan ini tersimpan dipekarangan dalam keadaan hidup.

Budidaya tanaman obat dapat dilakukan dengan mudah dan dapat memberikan fungsi ganda baik sebagai tanaman panagan, tanaman hias, dan dapat dipergunakan sebagai bumbu masakan, sehingga sangat menguntungkan jika ditanam di pekarangan (Dewi \& Widiyawati, 2019). Hasil budidaya tanaman obat dapat juga digunakan sebagai bahan edukasi tanaman obat tradisional kepada anggota keluarga terutama anak-anak, dan dapat dikonsumsi untuk menjaga kesehatan tubuh.

Menurut Sugito, Susilowati, \& Kholif (2017) Pemanfaatan tumbuhan sebagai obat alternatif menimbulkan efek samping yang lebih kecil dibandingkan dengan obat-obatan kimia. Selain itu, tanaman obat dapat digunakan sebagai peningkat daya tahan tubuh dan tergolong mudah dimanfaatkan oleh setiap keluarga. Upaya penggunakan tanaman obat sebagai obat alternatif merupakan salah bentuk peran serta masyarakat sekaligus merupakan teknologi tepat guna yang potensial untuk menunjang kesehatan keluarga (Pambudi \& Erlangga, 2018).

Pekarangan adalah sebidang tanah yang berada di sekitar rumah dan dapat diusahakan dengan tujuan pemenuhan gizi melalui perbaikan menu keluarga (Putri, Asnawi, \& Hikmayani, 2010). Selain itu pekarangan didefinisikan sebagai sebidang tanah dengan batas-batas tertentu yang ada bangunan tempat tinggal dan mempunyai hubungan fungsional baik ekonomi, biofisik, maupun sosial budaya dengan penghuninya. Menurut Khomah \& Fajarningsih (2016) pekarangan merupakan lahan terbuka yang beradat di sekitar rumah dan merupakan lahan potensial yang dapat dimanfaatkan untuk budidaya beberapa tanaman.

Lahan pekarangan yang sempit tidak memungkinan untuk dimanfaatkan sebagai lahan usaha pertanian yang kompleks, karena itu dianjurkan penanaman sayuran hijau dan tanaman obat. Bedengan untuk menanam sayuran juga tidak memerlukan tanah yang luas, sehingga sangat memungkinkan untuk dibudidayakan di pekarangan. Karena umumnya seseorang bosan makan sayuran sejenis secara terus-menerus, maka dapat dilakukan penanaman beberapa jenis sayuran (Oktalina, Wiyono, \& Hidayat, 2018).

Lahan pekarangan di RT.03/RW.XVII Kelurahan Sumber belum sepenuhnya dikelola secara intensif, sehingga perlu tambahan informasi terkait pemanfaatan lahan pekarangan sebagai penambah gizi, pendapatan, dan sumber pengobatan keluarga. Tambahan informasi ini diharapkan dapat membantu masyarakat dalam pemanfaatan lahan pekarangan sebagai upaya 
peningkatan kesejahteraan masyarakat. Tujuan dari kegiatan pengabdian kepada masyarakat ini adalah meningkatkan pemanfaatan lahan pekarangan dengan tanaman hortikultura dan tanaman obat keluarga (TOGA).

\section{Metodologi}

Kegiatan Pengabdian Kepada Masyarakat dilaksanakan di RT.03/RW.XVII, Kelurahan Sumber Kecamatan Banjarsari, Kota Surakarta tentang pemanfaatan lahan sempit untuk meningkatkan gizi, pendapatan keluarga, dan sumber pengobatan bagi keluarga diikuti oleh ibu-ibu anggota PKK sebagai peserta pengabdian.

Tahapan pengabdian kepada masyarakat yang dilakukan mencakup 3 (tiga) kegiatan yaitu: Persiapan, Pelaksanaan, dan evaluasi.

\section{A. Persiapan.}

Pada tahap ini dilakukan penentuan lokasi dan sasaran, analisis situasi, dan penyusunan materi yang akan disampaikan pada saat penyuluhan. Persiapan dilakukan pada tanggal 23 Februari 2020.

\section{B. Pelaksanaan.}

Pada tahap ini masyarakat diberikan pengetahuan tentang lahan pekarangan, dilanjutkan dengan penanaman sayuran dan tanaman obat keluarga di lahan pekarangan yang sempit. Tahap pelaksanaan dibagi menjadi 3 (tiga) kegiatan pokok yaitu : 1) Persiapan lahan pekarangan dengan membuat bedengan dilaksanakan tanggal 07 Maret 2020; 2) pemberian materi dan diskusi dilaksanakan tanggal 08 Maret 2020; 3) Penanaman di lahan pekarangan oleh ibu-ibu PKK didampingi dengan tim pengabdian yang dilaksanakan pada tanggal 23 Maret 2020.

\section{Evaluasi.}

Pada akhir kegiatan dilakukan evaluasi untuk melihat keberhasilan kegiatan yang dilaksanakan. Pada tahapan ini tim pengabdi melalukan 2 (dua) kali kunjungan pada saat pemeliharaan dan panen untuk melihat keberhasilan kegiatan.

\section{Hasil dan Pembahasan}

\section{A. Hasil}

Lahan yang digunakan untuk pengabdian merupakan lahan pekarang yang selama ini tidak dimanfaatkan oleh pemiliknya. Lahan pekarangan dipenuhi dengan rumput liar dan seringkali digunakan sebagai lahan pembuangan sampah oleh warga sekitar terlihat pada Gambar 1. 


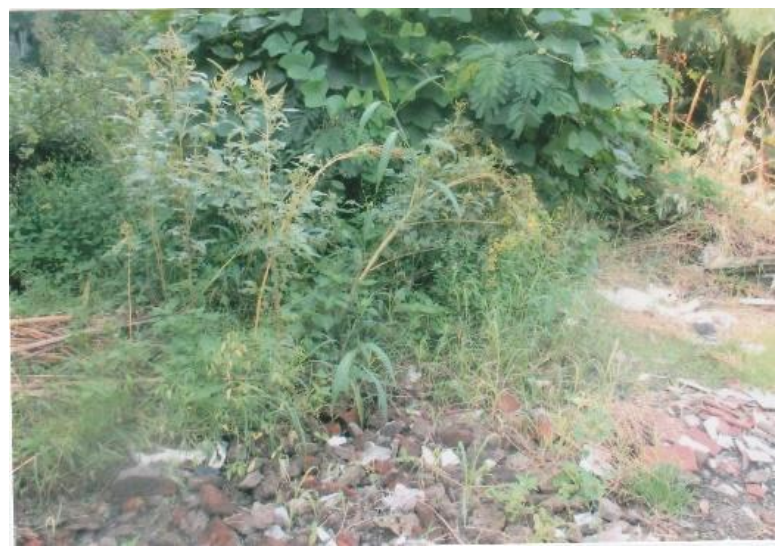

Gambar 1. Lahan Pekarang Sebelum Dikelola

Lahan pekarangan milik warga yang tidak terpakai harus diolah terlebih dahulu dengan dibentuk guludan-guludan dan diberi pupuk dasar berupa pupuk kandang terlihat pada Gambar 2. Setelah seminggu dari pemupukan dasar, warga diajak untuk menanam tanaman hortikultura dan tanaman obat bersama. Jenis tanaman hortikultura yang ditanam adalah sawi, bayam, kangkung, dan kacang panjang. Sedangkan tanaman obat yang ditanam adalah jahe dan kunyit.

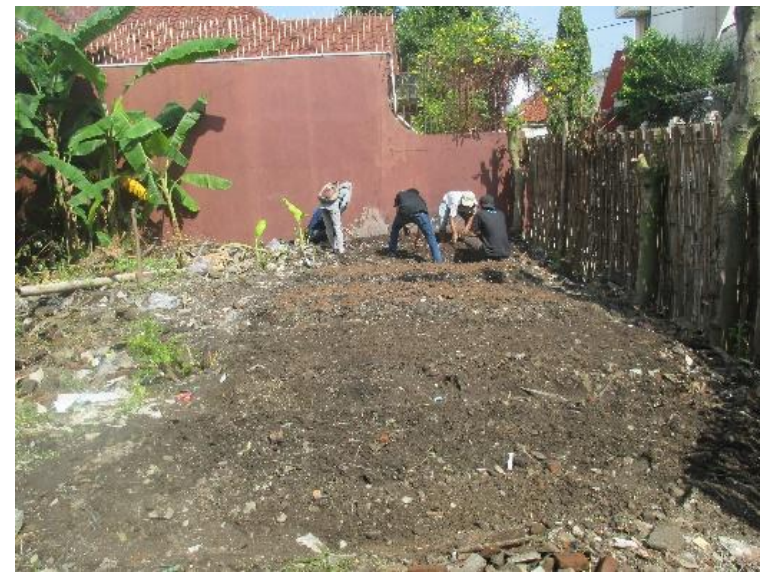

Gambar 2. Pengolahan Lahan Pekarang

Kegiatan selanjutnya yang dilakukan adalah penanaman tanaman hortikultura dan tanaman obat dengan melibatkan ibu PKK secara langsung, hal ini terlihat pada Gambar 3.

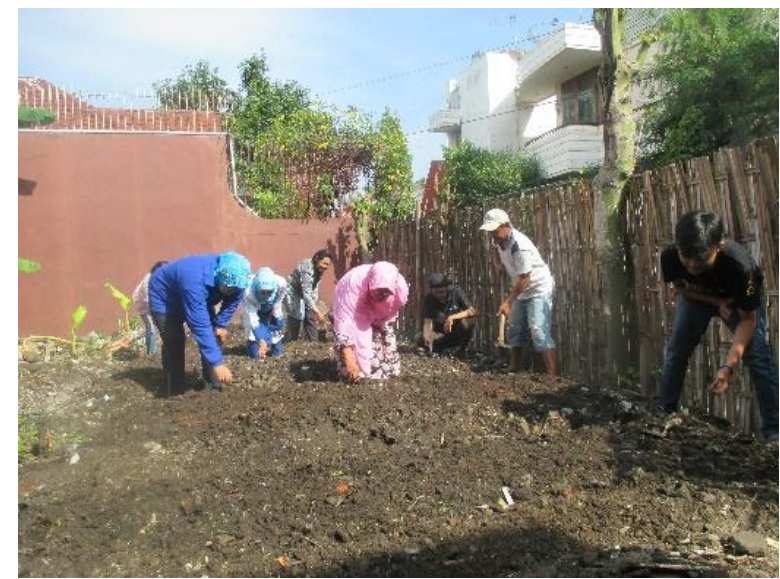

Gambar 3. Kegiatan Penanaman dengan Ibu PKK 
Seluruh peserta dalam kegiatan pengabdian antusias pada setiap kegiatan mulai dari penyuluhan hingga praktik di lapang, sehingga lahan pekarangan yang tadinya terbengkalai menjadi lahan pekarangan yang bermaanfaat, hal ini telihat pada Gambar 4.

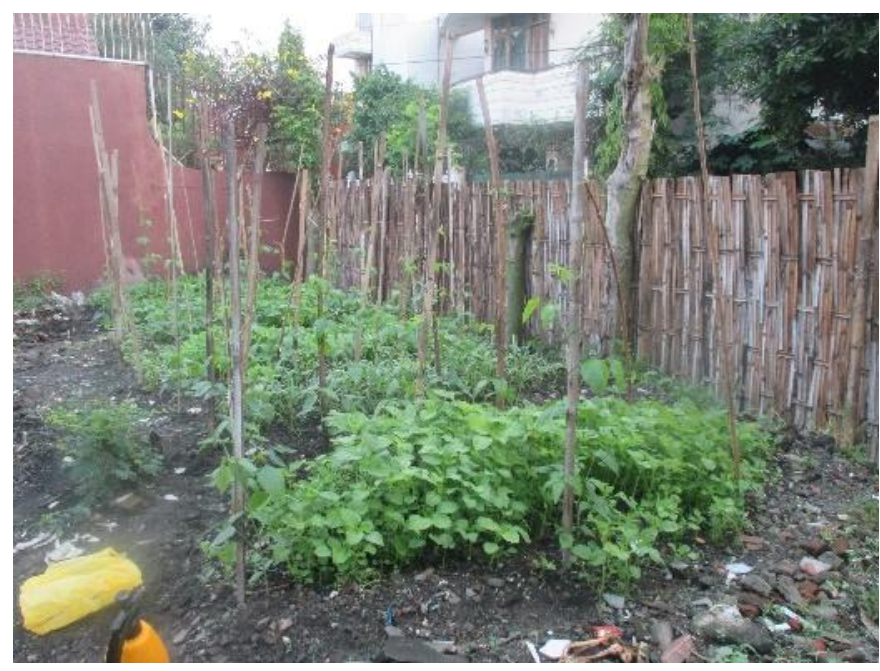

Gambar 4. Lahan pekarang yang telah ditanami

\section{B. Pembahasan}

Kegiatan pengabdian ini diawali dengan persiapan materi diskusi, persiapan lahan pekarangan yang akan diolah, dan bibit maupun benih tanaman yang akan ditanam. Pengabdian dimulai dengan ceramah dan diskusi mengenai problema kesehatan masyarakat pada umumnya, dan bagaimana cara meningkatkan gizi dan pendapatan bagi keluarga. Pemberian ceramah atau penyuluhan yang dilakukan dapat memperkuat pemahaman peserta pengabdian sehingga keberhasilan kegiatan dapat tercapai (Trisnaningsih, Wahyuni, \& Nur, 2019).

Sebenarnya masalah kesehatan, gizi dan peningkatan pendapatan ini dapat diatasi sendiri oleh masyarakat jika yang bersangkutan mampu mengelola dan mengoptimalkan potesi lahan pekarangan maupun lahan yang tak terpakai disekitar lingkungan tempat tinggal. Tim pengabdian memberikan contoh pemanfaatan lahan yang terbengkalai di lingkungan tempat tinggal warga, dengan menanam beberapa jenis tanaman obat (Kunyit dan jahe) dan sayuran berumur pendek (bayam, kangkung, sawi, dan kacang panjang) yang dapat digunakan sebagai tambahan pemenuhan gizi harian. Selain itu, hasil panen dapat diperjual-belikan jika ada kelebihan panen dan mulai bisa dinikmati hasil panennya setelah 30 hari penanaman. Waktu panen yang relatif singkat dan proses penanaman yang cukup mudah menjadikan anggota masyarakat di RT.03/RW.XVII Kelurahan Sumber Kecamatan Banjarsari Kota Surakarta mudah memahami manfaat dari pemanfaatan lahan pekarangan yang dimiliki dan tertarik untuk mempraktekkannya lebih lanjut.

Transfer teknologi yang dilakukan pada pengabdian ini dimulai dengan mengadakan penyuluhan kepada ibu-ibu PKK di lingkungan RT.03/RW.XVII Kelurahan Sumber Kecamatan Banjarsari Kota Surakarta. Penyuluhan yang dilakukan dimaksudkan untuk memberikan pengetahuan akan pentingnya pengelolaan lahan pekarangan yang tidak dipakai sehingga dapat menjadi sumber gizi, tambahan pendapatan, dan sumber pengobatan bagi keluarga. Penyuluhan juga dilakukan untuk memberikan informasi terkait teknik budidaya tanaman hortikultura dan tanaman obat khususnya jenis tanaman yang akan dibudidayakan. Kegiatan penyuluhan disampaikan secara langsung menggunakan power point dan video tentang pentingnya memanfaatkan lahan pekarangan untuk sebagai upaya pemenuhan gizi, peningkatan pendapatan, dan sumber pengobatan keluarga. 
Setiap tahapan yang dilakukan merupakan cara untuk mempermudah sasaran menerima ilmu pengetahuan mengenai teknik budidaya tanaman hortikultura dan tanaman obat. Pada saat penyuluhan juga dibuka sesi diskusi untuk menjawab pertanyaan dan rasa keingintahuan para ibu PKK. Masyarakat cukup antusias mengajukan pertanyaan terkait teknik, peluang, dan hambatan dalam budidaya tanaman hortikultura dan tanaman obat. Beberapa peserta kegiatan memiliki pengalaman bercocok tanam sehingga sudah pernah atau sedang membudidayakan tanaman hortikultura dan tanaman obat, tetapi beberapa peserta belum atau tidak pernah melakukan budidaya.

Kegiatan selanjutnya adalah budidaya tanaman hortikultura dan tanaman obat yang diikuti langsung oleh ibu PKK. Dengan adanya lahan percontohan, para ibu PKK dapat mempraktekkan secara langsung pengetahuan yang diperoleh dari penyuluhan dan pelatihan yang telah dilakukan sebelumnya. Tanaman obat yang ditanam meliputi jahe dan kunyit, sedangkan tanaman hortikultura yang ditanam adalah sawi, kangkung, bayam, dan kacang panjang. Menurut Haerudin (2010) praktek langsung kepada masyarakat memberikan dampak yang baik untuk memotivasi masyarakat dalam mempraktekkan lebih lanjut.

Sayuran hasil panen dari pekarangan dan dibudidayakan sendiri tentunya lebih berkualitas. Hal tersebut dikarenakan dalam praktek budidayanya dilakukan secara organik, karena itu, upaya pengoptimalisasian pekarangan melalui kegiatan budidaya sayuran itu penting karena menjamin ketersedaan bahan pangan yang berkualitas. Selain itu, pemanfaatkan lahan pekarangan dengan budidaya sayuran dan tanaman obat akan membantu sumber pengobatan keluarga dengan pemanfaatan kunyit dan jahe sebagai obat tradisional yang kaya akan antioksidan dan dapat menjaga imun di mas pandemi covid-19 ini.

\section{Simpulan}

Berdasarkan hasil kegiatan pengabdian kepada masyarakat ini dapat disusun kesimpulan bahwa umumnya lahan di RT.03/RW.XVII Kelurahan Sumber Kecamatan Banjarsari Kota Surakarta belum dimanfaatkan secara optimal dan banyak yang dibiarkan terbengkalai. Dengan mengikuti ceramah dan diskusi pada pertemuan PKK ini terlihat adanya respon positif dari ibuibu untuk mempelajari dan mencoba secara langsung memanfaatkan lahan pekarangan yang ada dengan menanam beberapa jenis sayuran berumur pendek dan tanaman obat.

\section{Ucapan Terima Kasih}

Ucapan terima kasih disampaikan kepada Universitas Slamet Riyadi Surakarta selaku pemberi dana kegiatan pengabdian masyarakat, anggota PKK RT.03/RW.XVII Kelurahan Sumber Kecamatan Banjarsari Kota Surakarta yang aktif mengikuti setiap tahapan pengabdian yang dilaksanakan, serta seluruh tim pengabdian yang membantu kesuksesan kegiatan.

\section{Daftar Pustaka}

Ashari, Saptana, \& Purwantini, T. B. (2012). Potensi Dan Prospek Pemanfaatan Lahan Pekarangan Untuk Mendukung Ketahanan Pangan. Forum Penelitian Agro Ekonomi, 30(1), 13-30

Dewi, prita sari, \& Widiyawati, I. (2019). Pengenalan Teknologi Budidaya Tanaman Obat sebagai Upaya Pemanfaatan Lahan Pekarangan di Kelurahan Pabuwaran Purwokerto , Jawa Tengah. Jurnal Panrita Abdi, 3(2), 105-112 
Dwiratna, Widyasanti, \& Rahmah. (2016). Pemanfaatan Lahan Pekarangan dengan Menerapkan Konsep Kawasan Rumah Pangan Lestari. Jurnal Aplikasi Ipteks Untuk Masyarakat, 5(1), 19-22. https://doi.org/10.2134/jeq2004.0288

Haerudin. (2010). Pemanfaatan Lahan Pekarangan Sebagai Desa Wanasaba Kecamatan Wanasaba Kabupaten Lombok Timur. Jurnal EducatiO, 5(1), 11-25

Khomah, I., \& Fajarningsih, R. U. (2016). Potensi dan Prospek Pemanfaatan Lahan Pekarangan terhadap Pendapatan Rumah Tangga. In Peningkatan Kapabilitas UMKM dalam Mewujudkan UMKM Naik Kelas Pemanfaatan (Vol. 1, pp. 155-161)

Lais, H., Pangemanan, paulus A., \& Jocom, S. G. (2017). Pemanfaatan Pekarangan Keluarga Petani Di Desa Para-Lele, Kecamatan Tatoareng, Kabupaten Kepulauan Sangihe. AgriSosioEkonomi Unsrat, 13(3A), 373-384

Oktalina, S. N. O., Wiyono, W., \& Hidayat, R. (2018). Pendampingan Pemanfaatan lahan Pekarangan Di Desa Banjararum Kecamatan Kalibawang Kabupaten Kulon Progo. Jurnal Pengabdian Dan Pengembangan Masyarakat, 1(1), 81-89. https://doi.org/10.22146/jp2m.41623

Pambudi, D. I., \& Erlangga, R. Y. (2018). Pemanfaatan Lahan Kosong Sebagai Tanaman Obat Keluarga Warga Prancak Dukuh Panggungharjo, Sewon, Bantul, Yogyakarta. Jurnal Pemberdayaan: Publikasi Hasil Pengabdian Kepada Masyarakat, 2(2), 347-352

Putri, H. M., Asnawi, \& Hikmayani, Y. (2010). Pemanfaatan Lahan Pekarangan Sebagai Bentuk Pemberdayaan Sosial Ekonomi Masyarakat Melalui Usaha Budidaya Lele. $J$. Bijak Dan Riset Sosek KP, 5(2), 159-167

Sugito, Susilowati, \& Kholif, M. Al. (2017). Strategi Pemanfaatan Lahan Pekarangan Untuk Budidaya Tanaman Obat Keluarga ( Toga ). Penamas Adi Buana, 02(2), 1-8

Trisnaningsih, U., Wahyuni, S., \& Nur, S. (2019). Pemanfaatan Lahan Pekarangan Dengan Tanaman Obat Keluarga. JPPM (Jurnal Pengabdian Dan Pemberdayaan Masyarakat), 3(2), 259-263. https://doi.org/10.30595/jppm.v3i2.4554 